\title{
粉末 X線回折プロファイル関数の開発
}

\author{
名古屋工業大学セラミックス基盤工学研究センター 井田 隆
}

\begin{abstract}
Takashi IDA: Development of Model Profile Functions for Powder X-Ray Diffractometry
\end{abstract}

A model peak profile function synthesized by multiple convolutions of the intrinsic peak profile with the instrumental functions of a conventional powder X-ray diffractometer has been developed. The general recipe for deriving accurate instrumental functions as well as an efficient numerical method for evaluating the convolutions are presented. The validity of the model function has been examined by comparing the experimental peak profiles measured in different conditions. The use of the convoluted model profile function provides a convenient and reliable way to estimate the integrated intensities, intrinsic peak positions and broadenings.

\section{1. はじめに}

粉末X線回折デー夕から結晶構造を決定するには, 各回 折ピークがどの $h k l$ 反射によるものかを決め（指数付け）, それぞれのピークについての積分強度を求めればよい.十 分な数の積分強度デー夕 $\left\{I_{h k l}\right\}$ が得られれば, 最小二乗法 により原子位置や温度因子などの構造パラメータが求めら れ，また正しい構造因子の位相が決まれば原理的には Fourier 変換により電子密度分布が求められるはずである ということは, 単結晶を用いた回折法と同じことである.

粉末回折データでは面間隔 $d$ の值の近い反射ピークの 裾が重なって各ピークの積分強度を見積もることが困難に なる傾向がある．しかし，ピークの形状をモデル化する関 数 (プロファイル関数) を用いたフィッティング法を利用 すれば, バックグラウンドの分離や複数のピークの分解を 同時に行えるので, 正確な積分強度の評価を実現すること ができる.そこで, 粉末法による構造解析の目的では, 細 かい実験条件の違いによるピーク形状の変化に柔軟に対応 して実測のピーク形状をよく再現できるようなプロファイ ル関数を開発することが強く望まれていた。

筆者は 1997 年頃から, 実測の粉末回折ピークの形状が 「試料の本質的な回折プロファイル」と「装置関数プロフ アイル」との多重のたたみこみであるという観点から, 物 理的な意味のあるパラメー夕によって定量的にピーク形 状を表現するようなプロファイル関数の形式を導く体系 的な方法論を確立して, これを基盤として粉末 $\mathrm{X}$ 線回折 を用いた構造評価の目的で有用なプロファイル関数を開 発することに取り組んできた。このような方法で導かれ
る新しいプロファイル関数によれば実測のピーク形状が よく再現できるだけでなく，回折装置の系統誤差による ピークのシフトを自動的に補正できることや, 試料の結 晶学的な不完全性に基づく本質的なピークの拡がり（ブ ロードニング）をより正確に評価できる可能性があるこ とがわかってきたので紹介したい.

\section{2. 装置関数}

はじめに, 装置関数の形式を導く一般的な方法につい て述べる.見かけの回折角 $2 \Theta$ と真の回折角 $2 \theta$ とのずれ $\Delta=2 \Theta-2 \theta$ の要因となるパラメータが $\alpha_{1}, \alpha_{2}, \ldots, \alpha_{n}$ で あり, パラメータ $\alpha_{1}, \alpha_{2}, \ldots, \alpha_{n}$ による強度分布関数がそ れぞれ $p_{1}\left(\alpha_{1}\right), p_{2}\left(\alpha_{2}\right), \ldots, p_{\mathrm{n}}\left(\alpha_{n}\right)$ であるとする。

まず, $\Delta$ を $\alpha_{1}, \alpha_{2}, \ldots, \alpha_{n}$ の関数 $\Delta\left(\alpha_{1}, \alpha_{2}, \ldots, \alpha_{n}\right)$ とし て表す．ただし，実際にはTaylor 展開の2 次形式：

$$
\begin{aligned}
\Delta \simeq \Delta_{0} & +\sum_{i=1}^{n}\left(\frac{\partial \Delta}{\partial \alpha_{i}}\right)_{0} \alpha_{i} \\
& +\frac{1}{2} \sum_{i=1}^{n} \sum_{j=1}^{n}\left(\frac{\partial^{2} \Delta}{\partial \alpha_{i} \partial \alpha_{j}}\right)_{0} \alpha_{i} \alpha_{j}
\end{aligned}
$$

で近似すればよい場合が多い.この式で添字の 0 は「 $\left\lceil\alpha_{1}=\right.$ $\alpha_{2}=\ldots=\alpha_{n}=0$ のときの值」であることを意味する.

このとき, 装置関数は回折角の「ずれ」を $x$ として

$$
\begin{aligned}
w(x)= & \int_{-\infty}^{\infty} \ldots \int_{-\infty}^{\infty} \delta\left(x-\Delta\left(\alpha_{1}, \ldots, \alpha_{n}\right)\right) \\
& \times p_{1}\left(\alpha_{1}\right) \ldots p_{n}\left(\alpha_{n}\right) d \alpha_{1} \ldots d \alpha_{n}
\end{aligned}
$$

と表される.ただし，ここで $\delta(x)$ はデル夕関数である.あ とはこの積分を解けばよいだけである．なお， $p_{1}\left(\alpha_{1}\right), \ldots$, 
$p_{\mathrm{n}}\left(\alpha_{n}\right)$ が規格化されていれば, $w(x)$ は $x$ について自動的に 規格化された関数になる。. 装置パラメー夕による強度分 布関数 $p_{i}\left(\alpha_{i}\right)$ は普通は有限な範囲で值を持つ単純な関数 で表されるので, 実際の積分の計算は場合分けが面倒た が根気がありさえすれば解ける場合が多い.

装置関数は極端に言えば装置ごとに異なっているのだ が, 以上のようなレシピに従えば，あまり深い洞察は必 要とされず,誰でもほぼ機械的に正しい装置関数が求め られるのではないかと思われる，以下の節では，このよ うな方法に従って実験室型粉末 $\mathrm{X}$ 線回折計の装置関数を 求めた実例 1)-3)について紹介する.

\section{1 軸発散効果の装置関数}

実験室型粉末回折計は図 1 のような光学系を持ってお り，図1の配置では水平面からずれたビームが一対のソ ーラースリットにより制限される構成になっている。制 限されているとは言っても，残ったビームのずれは回折 ピーク形状にかなり強い影響を及ぼし，回折ピークの形 状が低角反射では低角側に長い裾をひき，高角反射では 逆にやや高角側に裾をひく要因になっている。この効果 のことを軸発散効果と呼ぶ.

軸発散効果の定性的な説明についてはすでに知られて いたが,4)この効果を表す装置関数という意味では, 極端 に単純化された定性的なモデルしか知られておらず, 実 測の回折ピーク形状の定量的な解釈は困難であった。筆 者は以下の方法に従って, 1998 年に初めて実験室型粉末 回折計について軸発散効果の装置関数の正確な形式を導 いた.!

まず，入射ビームと回折ビームが垂直方向へそれぞれ角 度 $\alpha, \beta$ ずれたときについて考えて, 見かけの回折角 $2 \Theta$ と 真の回折角 $2 \theta$ の関係を求める. 単純な幾何学的な考察から

$$
\cos 2 \theta=\cos 2 \Theta \cos \alpha \cos \beta+\sin \alpha \sin \beta
$$

であることが導かれる。

つぎに, $\Delta \equiv 2 \Theta-2 \theta$ を $\alpha$ と $\beta$ の関数 $\Delta(\alpha, \beta)$ として表

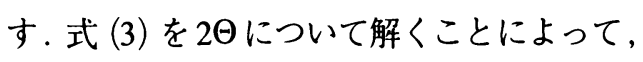

$$
\Delta=\arccos \left(\frac{\cos 2 \theta}{\cos \alpha \cos \beta}-\tan \alpha \tan \beta\right)-2 \theta
$$

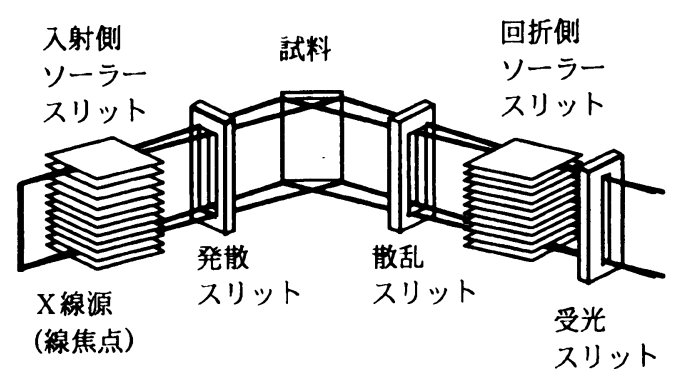

図1 実験室型粉末 X 線回折計の模式図. (Schematic illustration of a conventional powder X-ray diffractometer.)
の形が導かれるが, さらに Taylor 展開の 2 次形式を導くと,

$$
\Delta \simeq-\frac{\alpha^{2}+\beta^{2}}{2 \tan 2 \theta}+\frac{\alpha \beta}{\sin 2 \theta}
$$

という簡単な式が得られる。

垂直方向へのずれ角 $\alpha, \beta$ による強度の分布はソーラース リットにより制限されているので, 本来なら左右対称の二 等辺三角形で表されるような強度分布になるはずであるが， これを半値幅の等しい Gaussian 関数 (半値幅 $2 \sqrt{\ln 2} \psi$ )：

$$
f_{\mathrm{G}}(x ; \psi)=\frac{1}{\sqrt{\pi} \psi} \exp \left[-\left(\frac{x}{\psi}\right)^{2}\right]
$$

で近似することにすれば, デル夕関数 $\delta(x)$ を用いて装置 関数を

$$
w_{\mathrm{A}}(x)=\int_{-\infty}^{\infty} \int_{-\infty}^{\infty} \delta(x-\Delta) f_{\mathrm{G}}(\alpha) f_{\mathrm{G}}(\beta) d \alpha d \beta
$$

と書ける.この積分の解は

$$
w_{\mathrm{A}}(x)=\frac{2}{\pi \psi^{2}} \exp \left[\left(t-\frac{1}{t}\right) \frac{x}{\psi^{2}}\right] K_{0}\left[\left(t+\frac{1}{t}\right) \frac{|x|}{\psi^{2}}\right]
$$

となる.ただし,ここで $t \equiv \tan \theta$ とした. $K_{0}(x)$ は第 2 種変 形Bessel 関数という特殊関数であるが, 信頼性の高い数 值計算ルーチンを入手することは容易である.5) やや複 雑な形をしているが,この関数はこのままで規格化され た形式になっている．また，回折角 $2 \theta に$ 応じて，低角反 射では低角側に裾を引き，高角反射では高角側に裙を引 くという挙動をほほ忠実に再現することができる上に， パラメータ廿はソーラースリットによる角度制限の大き さという明確な意味を持っている。

\section{2 平板試料効果の装置関数}

集中法による測定の場合に，試料面が焦点円の曲率に 応じて湾曲していれば試料面のどの位置からの反射も同 じ回折角を持つ.しかし実際の測定では表面が平面的な 形状の試料を用いるので,これが収差の原因になる。こ の収差によって, 測定されるプロファイルが低角側に裾 を引き, ピークの位置も平均的には低角側にシフトする。 この効果を平板試料効果と呼ぶ.

図 1 の配置で水平方向への発散角をパラメータとして 考えれば, 前の節と同じ筋道に従って

$$
w_{\mathrm{F}}(x)=\left\{\begin{array}{cc}
1 / \sqrt{-4 \gamma_{\mathrm{F}} x} \text { for } & -\gamma_{\mathrm{F}}<x<0, \\
0 & \text { elsewhere }
\end{array}\right.
$$

という形式が容易に導かれる.2)ここで, 発散/散乱スリ ットの開き角 $\Phi_{\mathrm{H}}$ に対して, $\gamma_{\mathrm{F}} \equiv \Phi_{\mathrm{H}}^{2} / 2 \tan \theta$ と定義した

\section{3 試料の透過性の効果の装置関数}

X線に対する吸収係数が高い試料ではあまり問題にな らないが，とくに有機物などX 線をかなり透過する試料 では，X線が試料の内部に深く侵入できることが収差の 
原因となる。このような場合には試料の表面から奥の方 にずれた位置からの反射の寄与が無視できない．奥にず れた位置からの反射についての回折角は表面での反射に 比べて必ず高角側にずれるので, 結果として回折プロフ アイルが低角側に裾を引くような寄与が現れる。

試料の表面からの回折位置のずれをパラメータとして, 試料によるX線の吸収の効果を考慮することにすれば, 試料の透過性による収差関数は次の式で表されることが 自然に導かれる.3)

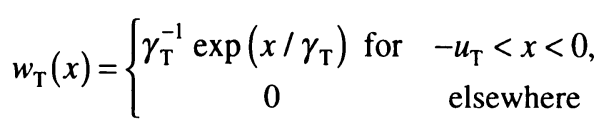

ただし, 試料の線吸収係数 $\mu$, 厚さ $T$, ゴニオメー夕半径 $R$ に対して,

$$
\begin{aligned}
& \gamma_{\mathrm{T}} \equiv \sin 2 \theta / 2 \mu R \\
& u_{\mathrm{T}} \equiv 2 T \cos \theta / R
\end{aligned}
$$

と定義する.

\section{$2.4 \mathrm{CuK} \alpha$ 線の分光特性}

$\mathrm{CuK} \alpha$ 線源の分光学的なプロファイルは, 次のような 2 つのLorentzian 型関数の和によって近似される.

$$
\begin{aligned}
& w_{\mathrm{X}}(x)=\sum_{i=1}^{2} f_{i} f_{\mathrm{L}}\left(x ; x_{i}, \gamma_{i}\right) \\
& f_{\mathrm{L}}\left(x ; x_{i}, \gamma_{i}\right)=\frac{1}{\pi \gamma_{i}}\left[1+\left(\frac{x-x_{i}}{\gamma_{i}}\right)^{2}\right]^{-1} \\
& x_{2}=2 \arcsin \frac{\lambda_{2} \sin \left(x_{1} / 2\right)}{\lambda_{1}} \\
& \gamma_{i}=\frac{\Delta \lambda_{i}}{\lambda_{i}} \tan \frac{x_{i}}{2}
\end{aligned}
$$

ここで $f_{i}, \lambda_{i}, \Delta \lambda_{i}$ は, それぞれ $\mathrm{K} \alpha_{i}$ ピークの強度, 波長， 半值幅で, $f_{1}=2 / 3, f_{2}=1 / 3 ; \lambda_{1}=1.5405981 \AA, \lambda_{2}=$ $1.54443 \AA ; \Delta \lambda_{1}=0.00058 \AA, \Delta \lambda_{2}=0.00077 \AA$ という 值6)を用いればよい。

\section{5 受光スリットの幅}

図1のようにX線源としては線焦点 (line focus) の配 置が用いられ，もう一方の焦点位置には受光スリットが 設置される．線源が線焦点であるとは言っても現実には 有限の幅を持っているのであるが, 通常は受光スリット 幅が $\mathrm{X}$ 線源の有効幅に比べて広いので, 装置の基本的な 分解能はほほ受光スリットの幅 $W_{\mathrm{R}}$ とゴニオメータ半径 $R$ の比で決まると考えてよい. 装置の分解能がプロファイ ルに及ぼす影響は, 以下の Gaussian 関数 (正規分布関数) で表現されるとする。

$$
\begin{aligned}
& w_{\mathrm{R}}(x)=\frac{1}{\sqrt{\pi} \gamma_{\mathrm{R}}} \exp \left[-\left(\frac{x}{\gamma_{\mathrm{R}}}\right)^{2}\right] \\
& \gamma_{\mathrm{R}}=\frac{\arctan \left(W_{\mathrm{R}} / R\right)}{2 \sqrt{\ln 2}}
\end{aligned}
$$

\section{3. たたみこみの計算}

以上のように回折計の装置関数の形式を導くことがで きたとしても，実際にどのようにたたみこみを計算する かは大きな問題である.

特殊な場合にはたたみこみを解析的に解くことができた り, 高精度な近似形式が得られることもあるが，一般的に は解けるとは限らないので, 数值的な計算が必要になる。

たたみこみの定義式：

$$
f(x) \otimes g(x) \equiv \int_{-\infty}^{\infty} f(x-y) g(y) d y
$$

について Simpson 法や Gauss-Legendre 法などのいわゆる 「数值積分」5)を実行することは, 一見素朴な数值計算の 方法であるように見える. 数值積分は被積分関数, ここ では $f(x-y) g(y)$ の有限な標本点 $\left\{y_{i} ; i=1 \ldots N\right\}$ での 值から積分值を求めるもので, 標本点の数を増やしてい けば限りなく正解に近付くことが保証されている．

しかし, 非線形最小二乗法によるプロファイルフィッ ティングに利用することを考えると，あまり多くの標本 点を取って計算時間を増やすことは望ましくない．その 一方で, 標本点の数を少なくすると計算されたプロファ イルに標本点の間隔をもった余計な波うちが現れる傾向 がある。この問題はかなり深刻で，見た目では目立たな い波うちであっても，非線形最小二乗法の収束の効率が 極端に低下する場合がある。

うまい方法がないかと考えているうちに, $f(x)$ と $g(x)$ の原始関数がわかっているときには, それを利用できるの ではないかと思い付いた.7) 例えば, $f(x)$ と $g(x)$ の原始関 数をそれぞれ $F(x), G(x)$ とすれば,

$$
\xi=G(x[F(x)-F(x-y)] /[F(x)-F(0)])
$$

という変数変換を施せば

$$
\frac{d \xi}{d y}=f(x-y) g(y)
$$

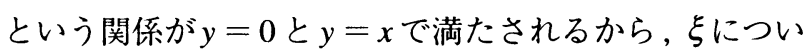
ての積分は被積分関数がほほ一定の值を取り数值積分が 容易になると考えられる．

図 2 にはLorentzian 関数と平板試料効果装置関数のた たみこみを，実際に变数変換を用いた数值積分によって 計算した例を示す．数值積分の標本点としてはたった 3 点しか使っていないが, 变数変換を施した数值積分では 


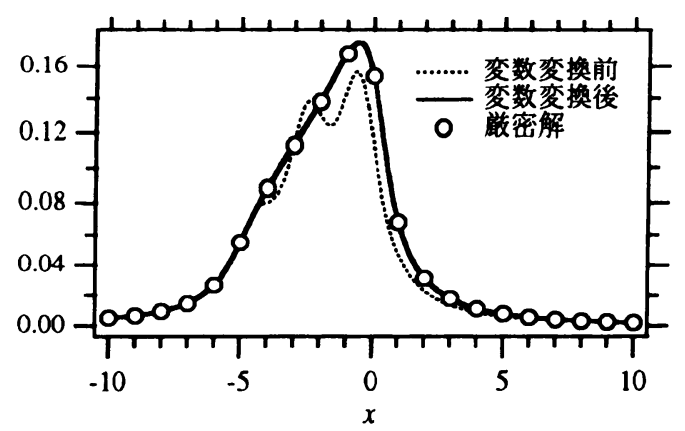

図2 Lorentzian と平板試料効果装置関数のたたみこみ. (Convolution of Lorentzian and flat-specimen abberation functions.) 白丸は厳密解で, 点線/実線は変数 変換前／後の 3 点 Gauss-Legendre 積分の結果を示す.

厳密解とほとんど区別がつかないほどよく一致した結果 が得られている。

ここではあらかじめ「たたみこまれる関数」の厳密な原 始関数がわかっている場合を想定したが, 原始関数の厳 密解の代わりにかなり粗い近似解を使っても計算が効率 化されることがわかっている.3) また，ここで行っている のは単なる置換積分に過ぎないから，数值計算に用いる 標本点の数を増やせば限りなく正解に近づくという性質 は失われていない.

\section{4. 実験データの解析}

実際にたたみこみにより計算されるプロファイル関数 を用いて実測のピーク形状に対するフィッティングを行 ってみた.プロファイル関数は Lorentzian, Gaussian, 軸 発散効果, 平板試料効果, 透過性効果関数を 4 重にたたみ こんだ形式を持つものであるが, パソコンを使って実用 的な計算速度で非線形最小二乗フィッティングを実行で きる.実際のたたみこみ計算の詳細については原論文3)を 参照されたい。

\section{1 発散/散乱スリット幅によるプロファイルの変化}

粉末回折用の標準試料である $\mathrm{LaB}_{6}$ (NIST SRM660) に ついて, 開き角の異なる発散/散乱スリットを用いて回 折プロファイルを測定し比較を行った.2)なお，精密な格 子定数の見積もりが可能であるかを検討するために, 自 作の簡便な装置で測定時の温度を $299 \pm 1 \mathrm{~K}$ に制御した。

図3に3通りの条件で測定された回折ピークの形状と フィッティングの結果を示す.ここで, フィッティング を行っているとはいっても, 実測のピーク形状と形を合 わせるための可変パラメータはいっさい用いていないこ とを強調しておきたい. わずかなずれは残っているが, 実 測と計算された形状の変化の挙動は非常によく一致して おり，ここで用いたモデルが妥当であることを強く支持 した結果になっている。

モデルプロファイル関数は装置関数の影響をあらわに

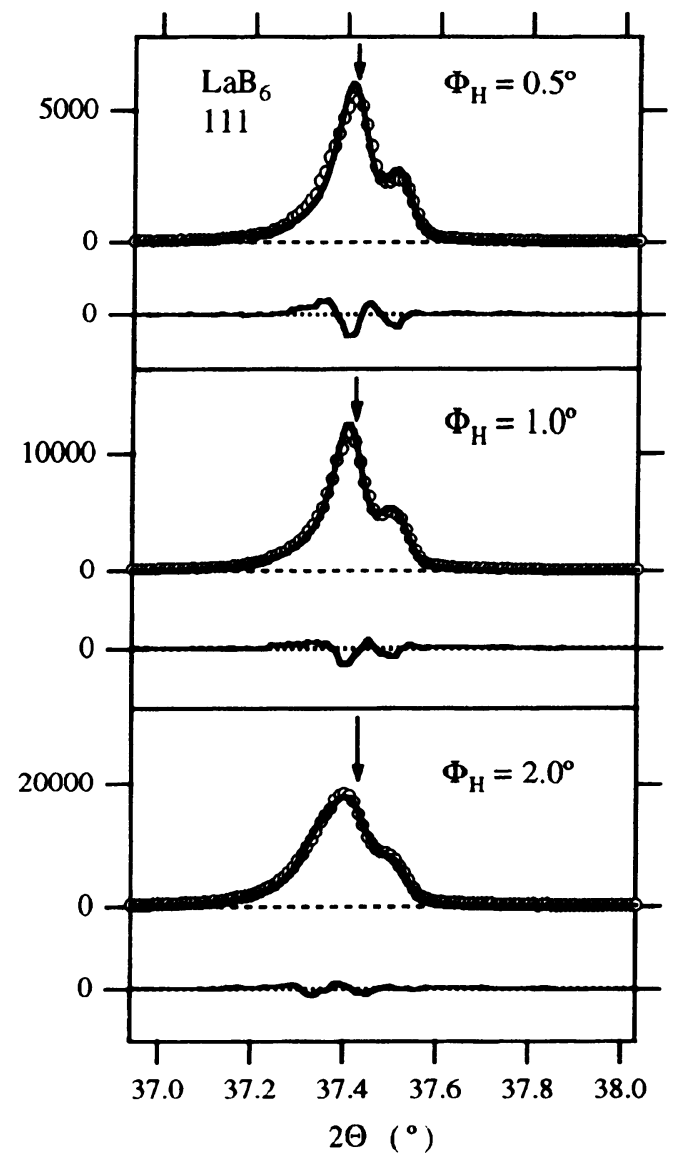

図3 $\mathrm{LaB}_{6}$ の 111 反射を 3 通りの発散/散乱スリット角 $\left(\Phi_{\mathrm{H}}=0.5,1,2^{\circ}\right)$ で測定したプロファイルと計算プロ ファイル. (Peak profiles of $\mathrm{LaB}_{6} 111$ reflection measured with 3 different divergence/scattering slit angles. Measured data and calculated profiles are plotted by open circles and solid lines, respectively.) 下部には差プロ ットを示している。

取り入れたものであるから,フィッティングにより見積 もられるピーク位置は原理的に「装置関数の影響を受け る前の本来のピーク位置」を意味するはずである．この ピーク位置を図の中で矢印で示した．実測の（見かけの） ピーク位置は実験条件によりかなり変化しているが, 確 かにこの矢印の位置は極めてよく一致している。ここで は変化の目立つ 111 反射ピークだけを示しているが, 他 の回折ピークについても同様の結果が得られており,こ のことは, プロファイル関数を用いることにより装置の 系統誤差が自動的に補正されていることを意味している ように思われる。

この 3 通りの測定について, プロファイルフィッティ ングにより求めた各回折ピークの位置から格子定数を見 積もった值 $a_{\mathrm{obs}}$ を図4 に白丸でプロットした，格子定数 の值は，もちろん本来ならば回折角によらず一定になる はずだが，ここで求められた值には，明らかに回折角に 依存した系統的な挙動が現れている。これは，いわゆる ピーク位置の系統誤差のうちで, プロファイル関数では 
考慮していない（i）ゴニオメータのゼロ調整誤差と（ii） 試料面位置のゴニオメータ中心からのずれの影響による ものと考えられる。

このことを考慮すればここで見積もられた「見かけ の格子定数」 $a_{\mathrm{obs}}$ は以下の式で表されるような回折角依存 性を持つことが予想される。

$$
a_{\mathrm{obs}}=\frac{a_{\mathrm{true}} \sin \left(\theta-\Delta 2 \Theta_{0} / 2+(S / R) \cos \theta\right)}{\sin \theta}
$$

ただし、ゴニオメータ半径を $R$ とする。この式には「真 の格子定数」 $a_{\mathrm{true}}$ とゼロ調整誤差角 $\Delta 2 \Theta_{0}$, 試料位置のずれ $S$ がパラメータとして含まれているが，これらをすべて 可変パラメータとして最小二乗法により $a_{\mathrm{obs}}$ のプロット にあてはめたものを図4では点線で示している．この図 から，たしかに $a_{\mathrm{obs}}$ の挙動はこの式によりよく表されて いることがわかる．また，フィッティングにより見積も られるゼロ調整誤差角と試料位置のずれは，いずれの場 合でもそれぞれ約 $-0.05^{\circ},-0.05 \mathrm{~mm}$ と見積もられた。こ の3つの測定は同じ装置を用いて同一試料について引き 続き測定されたものなので,これらの值がほほ一致して いることはリーズナブルである.

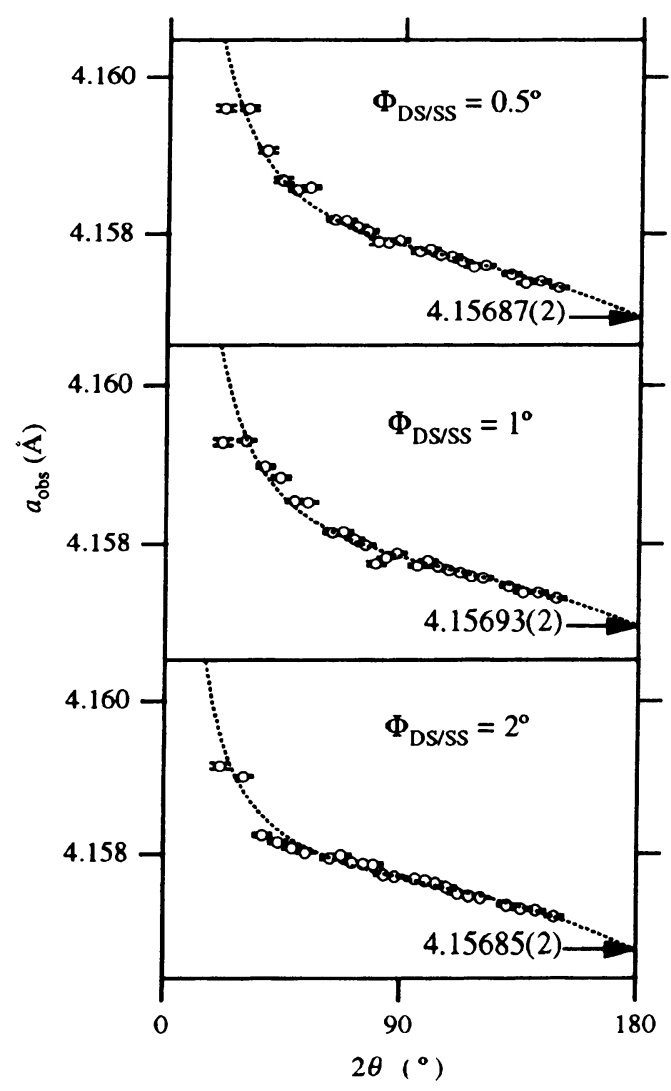

図4 $\mathrm{LaB}_{6}$ の各ピーク位置から見積もられた格子定数 (白 丸) と回折角依存性 (点線). (The lattice constant estimated by the peak positions (open circles) and the dependence on the diffraction angle (dotted lines).)
式 (21) の形から, フィッティング曲線を $2 \theta \rightarrow 180^{\circ}$ に外挿した值が真の格子定数 $a_{\mathrm{true}}$ の值に対応することが わかる. 図4 中にも示したように「真の格子定数」は 3 測 定のそれぞれから 4.15687 (2), 4.15693 (2), 4.15685 (2) Åと見積もられ，温度制御の誤差と試料の熱膨張率を考 慮に入れれば，試料に添付されている保証值4.15695（6） Åと実験誤差の範囲でいずれも一致するものであった．

従来は，精密な格子定数を求めるためには試料にあら かじめ格子定数のわかっている標準試料を均一に混合す る方法 (内部標準法) を用いることが常識であったが，こ こでは格子定数を決めるために内部標準を用いていない だけでなく，標準試料そのものをまったく使っていない にもかかわらず正確な格子定数が見積もられていること には注目すべきであろう。しかも測定自体は最も一般的 な市販の粉末回折計を用いたものであり，簡便な温度制 御装置以外に特殊な装置はいっさい使用していない.

\section{2 試料の透過性によるプロファイルの変化}

試料の透過性の効果について実験的に調べるために, 結晶構造そのものは変化させずに透過性のみがコントロ ールされた試料を以下のように調製した.3)

$\mathrm{X}$ 線に対する透過性の低い $\mathrm{LaB}_{6}$ 試料を, 透過性が高 く非晶質のデンプン $\left(\left[\mathrm{C}_{6} \mathrm{H}_{10} \mathrm{O}_{5}\right]_{n}\right)$ で希釈する． $\mathrm{LaB}_{6}$ の 粉末と水溶性デンプンの所定量に少量の水を加えてょく 練ると，均一性の高いペーストができる。このペースト を凍結乾燥すると煎餅状の試料が得られるので, これを 粉砕すれば $\mathrm{LaB}_{6}$ がむらなく希釈された粉末試料を得る ことができる.試料の透過性は $\mathrm{LaB}_{6}$ とデンプンの質量吸 収係数と混合比, 試料ホルダに充填した粉末の見かけの

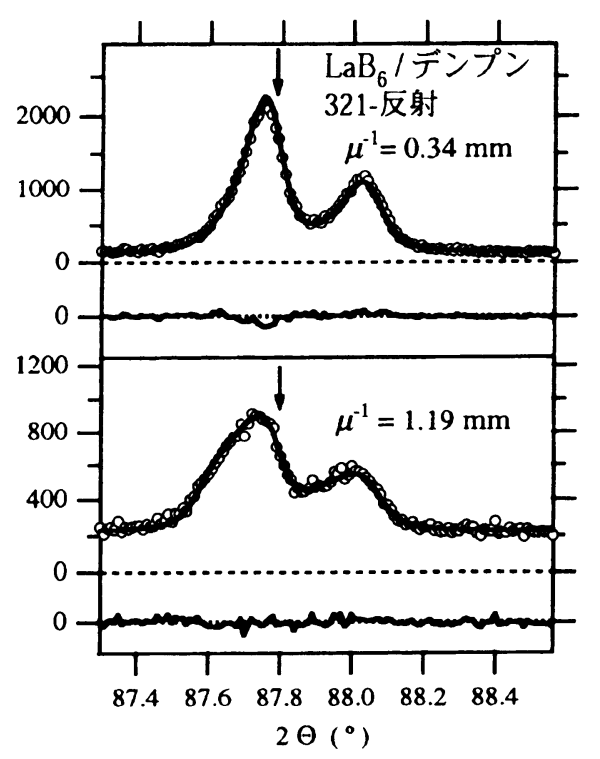

図 $5 \mathrm{LaB}_{6} /$ デンプン混合試料の実測プロファイルと計算 プロファイル. (Experimental and calculated peak profiles of $\mathrm{LaB}_{6} /$ starch mixture.) 下部には差プロットを 示している. 
密度とから計算できる。

図 5 はX 線の侵入深さ (線吸収係数の逆数) $\mu^{-1}$ が 0.34 $\mathrm{mm}$ と $1.19 \mathrm{~mm}$ と見積もられた 2 種類の試料の 321 -反射 の実測ピークプロファイルに対するフイッティングの結 果を示す. 試料の厚さは $0.5 \mathrm{~mm}$ なので, 侵入深さが試 料の厚さと同程度かそれ以上ということになり, 反射法 としては極端に透過性の高い条件で測定されている。

さて，図5に見られるように，試料の透過性が高くな るとプロファイルは大きく変形し, 見かけ上低角側へピ 一クがシフトするが，このような変化を計算プロファイ ルが非常によく再現できており，実測と計算とのずれに 系統的な挙動がほとんど含まれていない。

このフィッティングにおいて, 計算プロファイルでは形 状に影響を及ぽすパラメー夕はすべて固定した值を用いて いる. 原理的には試料の濃度や密度の不均一性, 試料の 結晶学的な不完全性, 寸法測定や密度評価の誤差などもプ ロファイルに影響を及ぼすはずであるから，このように実 測と計算が一致することは予想以上のことであった．

なお，前節と同様の方法で $\mathrm{LaB}_{6}$ の格子定数を見積もる

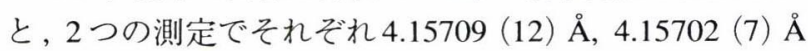
となり,やはりいずれの測定についても見積もられる格子 定数は実験誤差の範囲で保証值と一致した。つまり，透 過性が高い試料であっても標準試料を用いずに精密な格子 定数を見積もることが可能である. 標準試料を用いずにこ こまで正確な格子定数が見積もられるのは重原子を含み高 角反射まである程度の積分強度を示すような物質に限られ てくると思われるが，一度ゼ口調整䛊差角 $\Delta 2 \Theta_{0}$ を求めて おいて (このとき標準試料でなくても重原子を含む物質で ありさえすればよい)，以後はこれを固定したパラメー夕 として扱うという方法を取れば, 重原子を含まない試料に ついても精度の高い格子定数評価が可能である。もちろ ん，標準試料を使うことができるのならば，はじめは標 準試料の測定を行って同様の解析を行い, 格子定数を固定 したフィッティングによりゼロ調整䛊差角 $\Delta 2 \Theta_{0}$ を求めて おくという方法 (外部標準法) も推奨できる。

\section{5. おわりに}

装置関数をたたみこんだ形式の粉末回折プロファイル 関数を利用すれば, 実測プロファイルとよく一致すると いうことから積分強度をより正確に見積もることができ るというだけでなく，系統䛊差を補正したピーク位置を 簡便な方法で正確に評価することができる．

また，完全結晶を仮定したプロファイルモデルで実際 に $\mathrm{LaB}_{6}$ 試料の回折ピークプロファイルをほぼ完璧に再現 できたということは, 逆に任意の試料の結晶学的な不完 全性を，実測と計算のピーク形状のずれとして高感度に 検出しうるということを意味している。

ここで紹介した研究の主な部分は，筆者が姫路工業大 学理学部に在籍している間に行った. 万法論の実験的な 検証については木村啓作教授 (姫路工業大学) との共同研 究として実施したものである。

\section{文 献}

1) T. Ida: Rev. Sci. Instrum., 69, 2268 (1998).

2) T. Ida and K. Kimura: J. Appl. Cryst., 32, 634 (1999).

3) T. Ida and K. Kimura: J. Appl. Cryst., 32, 982 (1999).

4）虎谷秀穂：「実験化学講座 10 回折」丸善 (1992).

5) W. H. Press, B. P. Flannery, S. A. Teukolsky and W. T. Vetterling: "Numerical Recipes", Cambridge Univ. Press (1986).

6) A. H. Compton and S. K. Allison: "X-rays in Theory and Experiment", D. VAN NOSTRAND (1935).

7) T. Ida: Rev. Sci. Instrum., 69, 3837 (1998).

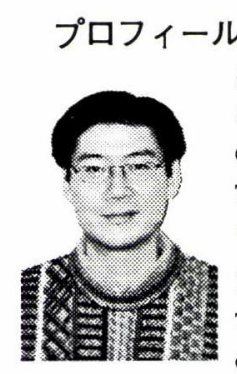

井田 隆 Takashi IDA

名古屋工業大学セラミックス基盤工学研究センター

Ceramics Research Laboratory, Nagoya Institute of Technology

厂507-0071 岐皁県多治見市旭ヶ丘 10-6-29

10-6-29 Asahigaoka, Tajimi, Gifu 507-0071, Japan

TEL. 0572-27-6811, FAX. 0572-27-6812

e-mail: ida@crl.nitech.ac.jp

最終学歴: 東京大学大学院理学系研究科化学専攻 修士課程

専門分野：X線結晶学, 固体物理学, 物理化学 現在の研究テーマ: 粉末回折の方法論

趣味: サッカー, 音楽, 水彩画 